\title{
European Association of Fish Pathologists
}

\author{
KAROLINA NAUMOWICZ, ELŻBIETA TERECH-MAJEWSKA*, \\ KRZYSZTOF WĄSOWICZ, ANDRZEJ K. SIWICKI**
}

\begin{abstract}
Katedra Patofizjologii, Weterynarii Sądowej i Administracji, *Katedra Epizootiologii, **Katedra Mikrobiologii i Immunologii, Wydział Medycyny Weterynaryjnej, Uniwersytet Warmińsko-Mazurski w Olsztynie, ul. Oczapowskiego 13, 10-719 Olsztyn
\end{abstract}

\section{Naumowicz K., Terech-Majewska E., Wąsowicz K., Siwicki A. K. European Association of Fish Pathologists}

Summary

Aquaculture is currently a rapidly growing branch of animal husbandry around the world. Its further development is expected due to the upcoming challenges related to climate changes. That is why an increased demand for specialists in this field, including veterinarians, is expected. The European Association of Fish Pathologists is an organization for veterinarians-ichthyopathologists from around the world founded over 40 years ago.

Keywords: veterinary association, ichthyopathology, fish pathology

\section{Powstanie EAFP}

Uczestnicy pierwszego spotkania Programu Współpracy w Dziedzinie Badań nad Akwakulturą (Co-operative Programme of Research on Aquaculture COPRAQ) EIFAC/OIE (European Inland Fisheries Advisory Commission/World Organisation for Animal Health), które miało miejsce w Zagrzebiu w 1975 r., docenili znaczenie bezpośredniego kontaktu między pracownikami badawczymi i potrzebę szybkiego rozpowszechniania informacji. Zasugerowano, że ważne informacje powinny być rozpowszechniane poprzez publikację ulotek i newsów w ramach działalności stowarzyszenia profesjonalistów, a nie poprzez komunikację zwykłymi kanałami. Jednym z wniosków końcowych spotkania było zalecenie stworzenia w tym celu stowarzyszenia patologów ryb.

Zdecydowana większość naukowców i pracowników zaangażowanych $\mathrm{w}$ badania nad chorobami ryb w całej Europie poparła utworzenie takiego stowarzyszenia, a pięcioosobowy komitet w składzie: R. Bootsma, B. J. Hill, R. J. Roberts, S. Sarig i P. E. Vestergård-Jørgensen, został wybrany przez głosowanie korespondencyjne. Komitetowi powierzono zadanie utworzenia Europejskiego Stowarzyszenia Ichtiopatologów. Pierwszym zadaniem komitetu organizacyjnego było sporządzenie listy znanych aktywnych badaczy w dziedzinie patologii ryb w Europie. Komitet organizacyjny opracował też statut Stowarzyszenia, który został omówiony i zatwierdzony na spotkaniu inauguracyjnym w Monachium w październiku 1979 r.

\section{Glówne cele działalności}

Cele nowo utworzonego Stowarzyszenia zostały zdefiniowane jako promowanie wymiany wiedzy i pomoc w koordynacji badań związanych z patologią ryb, mięczaków i skorupiaków. W tym celu zaproponowano, aby Stowarzyszenie rozpoczęło regularną publikację biuletynu. Członkostwo miało być otwarte dla wszystkich zainteresowanych: badaczy, studentów, organizacji, agencji lub innych stowarzyszeń, które chciały wspierać realizację celów Stowarzyszenia.

Rada oficerów zarządzających Stowarzyszeniem została wybrana na spotkaniu inauguracyjnym. Pod koniec pierwszych 6 miesięcy działalności Stowarzyszenia liczba członków wynosiła nieco ponad 50, a w Europie utworzono 11 oddziałów. Popularność głównej idei przyświecającej działalności EAFP znalazła odzwierciedlenie w ciągłym strumieniu zapytań od osób, które wyrażały chęć przystąpienia do Stowarzyszenia. Liczba członków wzrosła do ponad $90 \mathrm{w}$ pierwszym roku działalności.

\section{Zarząd}

W 2019 r. odbyły się wybory do Rady EAFP na kadencję 2019-2023. Nowa kadencja rozpoczęła się po Międzynarodowej Konferencji EAFP. Funkcję Przewodniczącego (EAFP President) od 2013 r. pełni José A. Garcia z Hiszpanii, a wybory dotyczyły stanowiska Wiceprzewodniczącego (EAFP Vice President), Oficera ds. Publikacji (EAFP Publications Officer) i Sekretarza Generalnego (EAFP General Secretary). $\mathrm{Na}$ stanowisko Oficera ds. Publikacji jednogłośnie został wybrany Sean Monaghan (druga kadencja z rzędu) z Wielkiej Brytani, a na stanowisko Sekretarza Generalnego jednogłośnie wybrano Snježanę Zrnčić (również druga kadencja z rzędu) z Chorwacji. Na stanowisko Wiceprzewodniczącego zgłoszono dwie kandydatury - Svena Bergmanna, Niemcy, oraz Edgara Bruna, Norwegia. Wybory przeprowadzono przy 
użyciu głosowania online przez oficjalną stronę internetową EAFP, które trwało od 20 maja do 21 czerwca 2019 r. Zwyciężył Egdar Brun z ilościa głosów 252 do 191 (4). Ponadto do przedstawicieli Rady EAFP zalicza się stanowisko Sekretarza Spotkań (EAFP Meeting Secretary), które od 2013 r. piastuje Ivona Mladineo z Chorwacji oraz stanowisko Skarbnika (EAFP Treasurer), które również od 2013 r. piastuje Klaus Knopf z Niemiec. Ponadto w zarządzie poza Radą znajduje się stanowisko Webmastera - od 2013 r. tę funkcję pełni Bartolomeo Gorgoglione z USA.

\section{Biuletyn Europejskiego Stowarzyszenia Ichtiopatologów (Bulletin of the European Association of Fish Pathologists)}

Biuletyn EAFP został uznany za formalny środek komunikacji w ramach działalności Stowarzyszenia i zaczął być wydawany we wrześniu 1981 r. Zmiana formatu $\mathrm{z}$ początkowo używanego newslettera na format biuletynu była natychmiastowym sukcesem i od tego momentu Biuletyn oraz EAFP jako organizacja zaczęły się dynamicznie rozwijać. Nadzieje, że Biuletyn będzie wydawany kwartalnie, wyrażone w pierwszym numerze, zostały spełnione. W 1987 r. liczbę wydań Biuletynu w każdym rocznym tomie zwiększono do pięciu, a od tomu 11 liczba wydań wzrosła do sześciu rocznie. Sukces EAFP wynikał (i wciąż wynika) w dużej mierze z serdeczności, poczucia wspólnoty i przyjaznej współpracy między entuzjastami dzielącymi zainteresowania badawcze. Jednakże jednym z głównych filarów Stowarzyszenia i najważniejszym powodem rosnącej popularności EAFP w początkowych latach działalności był sam Biuletyn.

Nie ma wątpliwości, że jego jakość wzrosła na przestrzeni lat, co znajduje odzwierciedlenie w fakcie, że aktualnie subskrybuje go około 50 bibliotek na całym świecie. Zarchiwizowane wydania są teraz dostępne do pobrania na stronie Stowarzyszenia za darmo, a od 2011 r. Biuletyn wydawany jest w pełnym kolorze. Ponadto w 2020 r. minie 40 lat od rozpoczęcia wydawania Biuletynu. Obecnie składa się on z sześciu regularnie wydawanych numerów rocznie oraz ewentualnych dodatkowych wydań specjalnych - w 2018 r. opublikowano dwa wydania specjalne.

\section{Rozwój Stowarzyszenia}

Od 1982 r. obserwowany jest ciągły wzrost liczby członków, ponadto coraz więcej krajów prosi o utworzenie kolejnych krajowych oddziałów EAFP. Do 1990 r. liczba członków Stowarzyszenia wzrosła do ponad 800, zrzeszając badaczy z 43 krajów, działających w 39 oddziałach krajowych, co sprawia, że EAFP jest niewątpliwie największym i najbardziej międzynarodowym z 4 głównych stowarzyszeń w dziedzinie patologii ryb, mięczaków i skorupiaków wodnych. W 1995 r. liczba członków w końcu osiągnęła, a nastepnie przekroczyła długo zakładany cel: 1000 osób z 57 krajów. W 1992 r. uzyskano wsparcie
Komisji Europejskiej w formie przyznania wsparcia finansowego na finansowanie kosztów dystrybucji Biuletynu przez 3 lata. Uznanie przez Europejską Wspólnotę Gospodarczą wartości EAFP dla szybkiego rozpowszechniania informacji o chorobach zwierząt wodnych za pośrednictwem Biuletynu było znaczącym poparciem dla rangi Stowarzyszenia i umożliwiło kontynuowanie Biuletynu na solidnych podstawach finansowych.

\section{Członkostwo}

Chociaż EAFP powstało i działa przede wszystkim w Europie, to członkostwo jest otwarte dla osób zainteresowanych ze wszystkich krajów na całym świecie, a utrzymywanie bliskich kontaktów międzynarodowych jest możliwe dzięki prężnie działającej sieci przewodniczących regionalnych. W 2019 r. łączna liczba aktywnie działających członków wyniosła 898 osób z 49 krajów, zorganizowanych w 37 oddziałach. Roczna opłata za członkostwo w 2019 r. wynosiła, odpowiednio: członkostwo indywidualne $-50 €$, studenckie $-25 €$, biblioteczne $-100 €$, wspierające $-400 €$. Formularze wniosku o członkostwo, szczegółowe informacje dotyczące płatności, a także dane lokalnego oddziału można znaleźć na stronie internetowej EAFP: www.eafp.org. W przypadku braku oddziału krajowego w danym państwie wnioski o członkostwo należy przesyłać do Sekretarza Generalnego EAFP: Snježana Zrnčić (e-mail: zrncic@irb.hr Croatian Veterinary Institute, Savska 143, 10000 Zagrzeb, Chorwacja).

\section{Działalność wydawnicza EAFP}

Opierając się na sukcesie Biuletynu EAFP, Rada Stowarzyszenia podjęła decyzję o rozszerzeniu działalności publikacyjnej, w związku z czym w 1992 r. jako pierwszy wydano „Podręcznik dla członków” („Members Handbook”). W 1995 r. opublikowano kolorowy przewodnik zatytułowany „Co powinienem zrobić? - przewodnik hodowcy ryb słodkowodnych" (,What should I do? - a Guide for the Freshwater Fish Farmer"; dostępny online: https://eafp.org/ wp-content/uploads/2015/02/WSID-FreshwaterEdition.pdf). Przewodnik ten otrzymał wsparcie Komisji Europejskiej, dzięki czemu został rozdany wszystkim członkom. Podobny przewodnik, tym razem dedykowany hodowcom ryb morskich (,What Should I Do? A Practical Guide for the Marine Fish Farmer", dostępny online: https://eafp.org/wp-content/ uploads/2015/02/WSID-Marine-Edition.pdf), został opublikowany w 1997 r., co więcej został również przetłumaczony na język hiszpański (,QQuédebohacer? - Un Manual Práctico Para El Maricultor”, dostępny online: https://eafp.org/wp-content/uploads/2015/02/ WSID-Marine-Edition-Spanish.pdf).

W miarę postępu technologii EAFP opublikowało osiem płyt CD-ROM, opartych na niezwykle popularnych i udanych warsztatach histopatologicznych, odby- 
wających się w ramach międzynarodowych konferencji EAFP. Dotychczas wydane płyty to: 2000 Neoplasia (CD-ROM); 2001 Histopathologyworkshops 19931999 (CD-ROM), obejmujący następujące zagadnienia:1993 - Heart and Liverpathology,1995 - Gill and Eyepathology, 1997 - Kidney and Pancreaspathology, 1999 - Brain and Skin pathology; 2003 Parasitology (CD-ROM); 2005 Reproductive \& early life stage pathology (CD-ROM); 2007 Cardiovascularpathology (CD-ROM); 2009 Gastrointestinalpathology (CDROM); 2011 Lymphoid organ pathology (including Musculoskeletal/Nervous system) (CD-ROM); 2013 Sensory systems pathology (CD-ROM).

Od 2015 r. publikacje na podstawie warsztatów histopatologicznych publikowane są wyłączenie online na głównej stronie EAFP, po zalogowaniu do strefy członkowskiej. Dotychczas opublikowane materiały to: 2015 - Gillspathology, 2017 - Artefacts in fishhistology, 2019 - Fish skin histopathology.

Ponadto w grudniu 2015 r. dzięki współfinansowaniu przez koncern „MSD Animal Health” opublikowano elektroniczny „Podręcznik badania anatomopatologicznego ryb" (,Fish Necropsy Manual”, dostępny online: http://www.necropsymanual.net/en/). Publikacja była owocem wieloletniej pracy czterech członków Stowarzyszenia: Patricii Noguera, Carmen Ubeda, Davida Bruno i Liliany Semenas. Podręcznik jest bardzo rozbudowany i zawiera nie tylko procedury przeprowadzania sekcji, ale także wiedzę dotyczącą anatomii, histologii, fizjologii i patologii ryb z rzędu łososiokształtnych Salmoniformes, flądrokształtnych Pleuronectiformes, dorszokształtnych Gadiformes, okoniokształtnych Perciformes, karpiokształtnych Cypriniformes i pielęgnicokształtnych Cichliformes.

\section{Międzynarodowe Konferencje EAFP}

Drugim głównym powodem prężnego rozwoju EAFP była ogromna popularność i sukces Międzynarodowych Konferencji EAFP, które organizowane są co 2 lata. Podobnie jak w przypadku biuletynu EAFP, wielu członków wyraziło pogląd, że międzynarodowe konferencje EAFP są najbardziej przyjaznymi i wartościowymi ze wszystkich międzynarodowych spotkań, w których mieli możliwość uczestniczyć. Zasadą przy organizacji jest naprzemienne wybieranie jako kraju organizującego raz kraju z południa Europy, a raz z północnej jej części. Do tej pory konferencje odbyły się w następujących lokalizacjach: 1983 Plymouth, Anglia, 1985 Montpellier, Francja, 1987 Bergen, Norwegia, 1989 Santiago de Compostela, Hiszpania, 1991 Budapeszt, Węgry, 1993 Brest, Francja, 1995 Palma, Hiszpania, 1997 Edynburg, Szkocja, 1999 Rodos, Grecja, 2001 Dublin, Irlandia, 2003 St. Julian's, Malta, 2005 Kopenhaga, Dania, 2007 Grado, Włochy, 2009 Praga, Czechy, 2011 Split, Chorwacja, 2013 Tampere, Finlandia, 2015 Las Palmas de Gran Canaria, Hiszpania, 2017 Belfast, Irlandia Północna, 2019 Porto, Portugalia. Najbliższa, jubile- uszowa 20. Międzynarodowa Konferencja EAFP odbędzie się we wrześniu 2021 r. w szkockim Aberdeen.

\section{Oddziały Krajowe EAFP}

Aktualnie w EAFP działa 37 zarejestrowanych oddziałów krajowych, do których należą przedstawiciele państw europejskich i nie tylko. Każdy oddział krajowy posiada przewodniczącego, który jest odpowiedzialny za organizację pracy na poziomie regionalnym. Obecni przewodniczący Oddziałów Krajowych to:

- Australia: Andy Barnes (a.barnes@uq.edu.au),

- Austria: Oliver Hochwartner (oliver.hochwartner @chello.at),

- Belgia: Francois Lieffrig (f.lieffrig@cergroupe.be),

- Chile: Pedro Smith (psmith@uchile.cl),

- Chorwacja: Ivona Mladineo (mladineo@izor.hr),

- Czechy: Stanislav Navratil (navratils@vfu.cz),

- Dania: Lone Madsen (loma@vet.dtu.dk),

- Finlandia: Satu Viljamaa-Dirks (satu.viljamaa-dirks (a)evira.fi),

- Francja: Sopie Labrut (sophie.labrut@labocea.fr),

- Grecja: Kantham Papanna (k.papanna@nireus.com),

- Hiszpania: Antonio J. Figueras-Huerta (pato1@iim. csic.es),

- Holandia: Olga L. M. Haenen (olga.haenen@wur.n),

- Indie: Yeshwant Khillare (khillareyk@rediffmail. com),

- Irlandia: John McArdle (mcardlej@eircom.net),

- Islandia: Arni Kristmundsson (arnik@hi.is),

- Izrael: Dina Zilberg (dzilberg@bgu.ac.il),

- Japonia: Masahiro Sakai (m.sakai@cc.miyazaki-u. ac.jp),

- Kanada: Simon Jones (simon.jones@dfo-mpo.gc.ca),

- Malezja: Sandra Catherine Zaninathan (sandra @umt.my),

- Malta: Jes Brinch-Iversen (jesbi@mac.com),

- Niemcy: Dirk Willem Kleingeld (dirk.kleingeld @t-online.de),

- Norwegia: Anne-Berit Olsen (anne-berit.olsen @vetinst.no),

- Polska: Andrzej Krzysztof Siwicki (aksiw@infish. com.pl),

- Portugalia: Francisco Ruano (fruano@ipma.pt),

- Republika Południowej Afryki: David A. Huchzermeyer (aquavet@telkomsa.net),

- Rosja: Anna Kazarnikova (kazarnikova@gmail. com),

- Rumunia: Calin-DecebalCojocaru (c cojocaru d (a)yahoo.com),

- Serbia:Vladimir Radosavljevic (vladimiradosavljevic (a)yahoo.co.uk),

- Słowenia: Vlasta Jencic (vlasta.jencic@vf.uni-lj.si),

- Szwajcaria: Thomas Wahli (thomas.wahli@ vetsuisse.unibe.ch),

- Szwecja: Johanna Näslund (johanna.naslund@slu.se),

- Tajwan: Shih-Chu Chen (scchen@mail.npust. edu.tw),

- Turcja: Soner Altun (saltun@uludag.edu.tr), 
- USA: Sarah L. Poynton (spoynton@jhmi.edu),

- Węgry: Csaba Székely (szekely.csaba@agrar.mta. hu),

- Wielka Brytania: David Verner-Jeffreys (david. verner-jeffreys@cefas.co.uk),

- Włochy: Marco Galeotti (marco.galeotti@uniud.it). W ramach działalności oddziałów krajowych organizowane są również krajowe lub jednojęzyczne spotkania naukowe. W ostatnich latach takie spotkanie odbyło się m.in. we Fryburgu w Szwajcarii, gdzie 17. wspólne spotkanie niemieckojęzycznych oddziałów EAFP (Niemiec, Austrii i Szwajcarii) zatytułowane „Zdrowie ryb - wyzwanie” (,Fish health - a challenge") zgromadziło 97 członków. Do udanych należało też 3. spotkanie oddziałów z Irlandii i Wielkiej Brytanii zorganizowane w Galway przez Irlandzki Instytut Morski (Marine Institute in Ireland) pt.: „Integracja środowisk akademickich $\mathrm{z}$ przemysłem $\mathrm{W}$ celu poprawy zdrowia zwierząt wodnych” („Connecting academia with industry for improving aquatic animal health"). Po sukcesie dwóch poprzednich edycji wydarzenia, w tym spotkaniu wzięło udział aż 85 uczestników, a delegaci przybyli również z takich krajów, jak Norwegia, Malta, Chorwacja i Malezja. Z kolei Francuski Oddział Krajowy EAFP zorganizował swoje 14. spotkanie jako niezależną sesję w ramach dorocznej konferencji Swiatowego Towarzystwa Akwakultury (World Aquaculture Society, WAS) i Europejskiego Towarzystwa Akwakultury (European Aquaculture Society, EAS) zorganizowanej w 2018 r. we francuskim Montpellier. W spotkaniu uczestniczyło około 25 członków francuskiego oddziału, a także wiele osób spoza EAFP. Oprócz regularnych spotkań Krajowych Oddziałów w 2017 r. spotkania EAFP odbyły się w Chile i Finlandii.

\section{Członkowie Honorowi EAFP}

Praca przewodniczących oddziałów krajowych przyczyniła się do sukcesu całego EAFP. W uznaniu zasług i szczególnych osiągnięć w 1991 r. Rada postanowiła ustanowić wyróżnienie w postaci nadania tytułu Członka Honorowego EAFP. Tytuł ten przyznawany jest osobom, które wykazały się wyjątkowym wkładem w rozwój Stowarzyszenia i wybitnymi osiągnięciami w dziedzinie, jaką jest patologia ryb. Do tej pory tytuł przyznano następującym osobom: David Alderman, David Bruno, Inger Dalsgaard, Trevor Evelyn, Olga L. M. Haenen, Tore Håstein, Barry Hill, Barbara Nowak, Hans-Jürgen Schlotfeldt, Patrick Smith. Tytuł Członka Honorowego nosili też wybitni, nieżyjący już badacze: Oleg N. Bauer, Niels O. Christensen, Syuzo Egusa, Jiří Lom, Wilhelm Schäperclaus, Stanislas F. Sniezko.

\section{Grupa Studentów i Młodych Badaczy EAFP}

Dzięki inicjatywie Rady EAFP dotyczącej utworzenia studenckiej grupy EAFP, 11 września 2019 r. podczas 19. Międzynarodowej Konferencji EAFP w Porto (, $19^{\text {th }}$ International Conference on Diseases of Fish and Shellfish in Porto") zorganizowano pierwsze spotkanie grupy (7). Wzięło w nim udział 27 studentów i młodych badaczy na wczesnym etapie rozwoju kariery naukowej. Spotkanie otworzył Jerko Hrabar, który przedstawił krótki program spotkania i zaprezentował przyszłe oczekiwania od grupy. Następnie Ivana Bušelić przedstawiła działania Grupy Roboczej Młodych Naukowców Euro Marine (Euro Marine Young Scientists Working Group) jako przykład stowarzyszenia studentów, na podstawie którego można zaplanować rozwój odpowiedniej grupy EAFP.

Po prezentacji odbyła się dyskusja między uczestnikami na temat ich poglądów, pomysłów i potrzeb dotyczących wzmocnienia pozycji studentów i młodych badaczy w ramach działalności EAFP. Jako kluczowe zadanie do realizacji wskazano stworzenie sieci pomiędzy członkami, zwłaszcza pracującymi w podobnych obszarach badawczych. Sieć miałaby ułatwić wymianę doświadczeń i wyjazdy międzynarodowe. Pod koniec spotkania przyznano Studencką Nagrodę za Najlepszy Plakat. Polska na spotkaniu reprezentowana była przez Karolinę Naumowicz.

\section{Członkowie wspierający}

Z pewnością dla rozwoju EAFP nie mniej ważny był istotny wkład członków wspierających. Członkami wspierającymi są organizacje komercyjne, które doceniają wartość głównych założeń przyświecających działalności EAFP i chcą pomóc w osiągnięciu sukcesów w ich realizacji. Obecnie w EAFP jest 22 członków wspierających i są wyszczególnieni na tylnej okładce Biuletynu. Należą do nich: Belgia: NUTRIAD INTERNATIONAL NV, Hoogveld 93, Dendermonde 9200, Chile: LABORATORIO PATHOVET, Palena 230, Puerto MonttVeHiCe, Libertad 590, Poblacion Egana, Puerto Montt, FISH PATHOLOGY, Libertad 590, Poblacion Egana, Puerto Montt, Dania: ALLER AQUA, Allervej 130, 6070 Christiansfeld, BIOMAR A/S, Mylius Erichsensvej 35, 7330 Brande, Francja: ICTYOGROUP, LD La Villate, 03170 Deneuille-les Mines Skretting Trouw France SA, Le Pont de Pierre, 02140 Fontaine les Vervins, VIRBAC, 13-eme Rue LID, 06511 Carros, Norwegia: Aqua Gen A/S, PO Box 1240, Pir-senteret, N-7462 Trondheim, AQUAMEDIC ASGaustadalleen 21, N-0349 Oslo, ELANCO Animal Health, Solheimsgaten 11, N-5958 Bergen, MSD Animal Health Innovation AS, Thormøhlengst. 55, N-5008 Bergen, PatoGenAnalyse AS, Service boks 9, N-6025 Ålesund, Skretting ARC AS, Postboks 48, N-4001 Stavanger, MOWI ASA, Pb 4102 Sandviken, Bergen, Hiszpania: CENAVISA S.L., Carrers del Boter 4, 43205 Reus, Tarragona, HIPRA S.A., Avd de la Selva 135, 17170 Amer-Girona, Szwajcaria: Hokovit Fishfeed, Industriestraße 27, CH-4922 Bützberg, Wielka Brytania: Fish Vet Group, 22 Carsegate Rd, Inverness IV3 8EXMSD, Animal Health UK, 2 St. Aylotts Cottages, Ashdon Road, Saffron Walden, 
Essex CB10 2NE, Ridgway Biologicals Ltd, Units 1-3 Old Station Business Park, Compton, Berkshire RG20 6NE.

\section{Nagrody i granty}

W ramach działalności EAFP organizowanych jest kilka stałych konkursów. Między innymi wszyscy studenci i młodzi badacze przed Międzynarodową Konferencją EAFP mogą ubiegać się o EAFP Student Awards. W 2019 r. swoje kandydatury zgłosiło 31 osób, jednakże nagrody zostały przyznane tylko 15 i laureatami zostali (2):

- Arndt Christian Hofmann (Friedrich-LoefflerInstitut, Niemcy),

- Athina Papadopoulou (Institute of Aquaculture, University of Stirling, Wielka Brytania),

- Cara Brosnahan (School of Veterinary Science, Massey University, Nowa Zelandia),

- Cecilia Power (RMIT University, Australia),

- Cuong Thanh Le (University of the Sunshine Coast, Queensland, Australia),

- Enrico Volpe (University of Bologna, Włochy),

- Karolina Naumowicz (Uniwersytet WarmińskoMazurski w Olsztynie, Polska),

- Lyndsay Christie (University of Bath/Cefas, Wielka Brytania),

- Rosa Inés Strem Cuellar (Ben Gurion University of the Negev, Izrael),

- Urvashi Goswami (School of Animal Science, Szent Istvan Uniwersity, Węgry),

- Valentina Laura Donati (Technical University of Denmark, Dania),

- Željko Pavlinec (Croatian Veterinary Institute, Chorwacja),

- Yuriy Rud (Institute of Fisheries, Ukraina),

- Chiraz Ben Saad (Faculty of Sciences of Tunis, Tunezja),

- Fatma El Zahraa Abdel Hameed Abdel-Rahman Ahmed (University of Veterinary Medicine, Austria). Ponadto podczas każdej Konferencji Międzynarodowej EAFP przyznawane są nagrody za najlepiej przygotowany poster (Conference Poster Prize). W 2019 r. laureatami nagród zostali:

- I miejsce: Yousaf Muhammad Naveed, Amin AB „Novel histological evidence of atrio ventricular (AV) node in Atlantic salmon (Salmo salar L.)";

- II miejsce: Kimberly A. Veenstra, R. Belmonte, K. Hodneland, E. Quillet, M. Kawanobe, M. Furihata, U. Fischer „Development of a model system for studying cell-mediated immune responses to salmonid alphavirus";

- III miejsce: Rhi Hunt, Jo Cable, Chris Williams „Shining a light on parasite control”.

W związku z małymi możliwościami uzyskania dofinansowania w dziedzinie ichtiopatologii od $2018 \mathrm{r}$. w ramach działalności EAFP przyznawane są również tzw. Małe Granty EAFP (Small Grants Scheme Awards, EAFP-SGS). Nadrzędnym celem grantów jest pomoc członkom EAFP w poznawaniu nowych metod oraz wspieranie współpracy pomiędzy różnymi badaczami, co stworzy możliwość wykorzystania w swojej pracy naukowej i dalszego rozwoju dziedziny, jaką jest ichtiopatologia. Aby otrzymać grant, należy zgłosić pomysł projektu, który jest poddawany rygorystycznej ocenie przez Radę EAFP. Autorom najlepszych propozycji przyznawane jest dofinansowanie do stażu naukowego w zaplanowanej instytucji goszczącej. Po realizacji projektu, beneficjenci zdają sprawozdanie w formie krótkiego artykułu, umieszczanego do wglądu członkom EAFP na oficjalnej stronie internetowej Stowarzyszenia. Obecnie trwa rekrutacja do drugiej edycji nagród (6). Poniżej wymienione są osoby i projekty, które uzyskały dofinansowanie w pierwszej edycji EAFP-SGS:

- Kerrie Ni Dhufaigh, projekt „Comparative proteomic profiling of pathogenic and non-pathogenic Neoparamoebaperurans proteins associated with Amoebic Gill Disease"; strona goszczaca Eugene Dillon, Proteomics Core z University College Dublin, Irlandia,

- Bartolomeo Gorgoglione, project „Common pathogens' co-infection in rainbow trout"; strona goszcząca Andrew Wargo, Virginia Institute of Marine Science, USA,

- Lisa Jordan, project „Taiwanese isolate of Koi Herpesvirus"; strona goszcząca Michael Wolff, University of Applied Sciences, THM, Niemcy,

- Khalid Shahin, projekt „Temporal immune responses induced following primary and booster mucosal vaccination regimes against Vibrio anguillarum in rainbow trout (Oncorhynchus mykiss)"; strona goszcząca Tharangani K. Herath, Department of Animal Production, Welfare and Veterinary Sciences Harper Adams University, Wielka Brytania,

- Anamarija Vrbatovic, project „Monogenean Sparicotylechrysophrii in the farmed sea bream", strona goszcząca Ariadna Sitja-Bobadilla, Instituto de Acuicultura Torre de la Sal (CSIC), Hiszpania.

W 2018 r. zorganizowano pierwszy konkurs na najlepszą fotografię opublikowaną w latach 2011-2015 w Biuletynie EAFP(EAFP Bulletin Best Picture Competition). Celem konkursu było rozbudzenie zainteresowania i zwiększenie czytelnictwa Biuletynu EAFP. Konkurs był promowany na stronie EAFP na Facebooku, a głosowanie odbyło się za pośrednictwem strony EAFP. Konkurs trwał ponad 6 tygodni plus tydzień finałowy, w czasie którego dokonano wyboru z 36 najciekawszych zdjęć biuletynu EAFP opublikowanych w latach 2011-2015. Zwycięskie zdjęcie zostało wykonane przez Carmen López Gómez (Centro de Investigacions Mariñas (CIMA), Hiszpania) wraz ze współautorami, M. Ruiz, S. Darriba i R. Rodríguez (5). W zbliżającej się edycji konkursu oceniane będą zdjęcia opublikowane w Biuletynie EAFP w latach 2016-2020. 


\section{Historia EAFP w Polsce}

EAFP jest aktywną organizacją od 1991 r. także w Polsce. Aktualnie polska gałąź obejmuje 11 osób, reprezentujących kilka ośrodków naukowych, a także wolną praktykę ichtiopatologiczną. Od momentu utworzenia grupy w Polsce, przewodniczącym jest prof. dr hab. Andrzej K. Siwicki reprezentujący Instytut Rybactwa Śródlądowego w Olsztynie oraz Uniwersytet Warmińsko-Mazurski w Olsztynie. Polscy członkowie EAFP reprezentowani są przez przedstawicieli: 2 osoby związane $\mathrm{z}$ ośrodkiem akademickim w Szczecinie, 2 osoby z placówką naukową w Gdyni, 2 osoby z placówką naukową w Puławach, 1 osoba reprezentuje ośrodek akademicki w Lublinie, 3 osoby są związane z placówką akademicką w Olsztynie, natomiast 1 osoba reprezentuje lekarzy weterynarii wolnej praktyki. Przewodniczący i członkowie starają się regularnie uczestniczyć w cyklicznych konferencjach organizowanych przez EAFP, gdyż stwarza to możliwość poznania wielu nowych aspektów tej wąskiej specjalności (3).

W Polsce członkowie oddziału współorganizowali dotąd dwie konferencje dotyczące problematyki chorób zwierząt akwakultury, w latach 2010 i 2011. Konferencje odbywały się na Wydziale Medycyny Weterynaryjnej Uniwersytetu WarmińskoMazurskiego w Olsztynie. Wydarzenia miały charakter naukowo-szkoleniowy i były adresowane do całego środowiska zajmującego się ochroną zdrowia i hodowlą zwierząt akwakultury. Po każdej z konferencji opracowano i wydano monografie, które do dzisiaj cieszą się zainteresowaniem i poczytnością. Pierwsze opracowanie nosiło tytuł „Choroby ryb podlegające obowiązkowi zwalczania oraz inne choroby zagrażające hodowli - diagnostyka, profilaktyka, terapia" (IRS Olsztyn, 2010), drugie natomiast było zatytułowane „Choroby mięczaków i skorupiaków podlegające obowiązkowi zwalczania" (IRS Olsztyn, 2011).

W Polsce jest znacznie więcej osób zajmujących się problematyką chorób ryb niż zrzeszonych $\mathrm{w}$ polskiej gałęzi EAFP. Są one rozproszone w wielu ośrodkach naukowych, ponadto należą do nich również lekarze weterynarii wolnej praktyki. Lekarzy specjalistów chorób ryb jest aktualnie 88 , wraz z osobami niepraktykującymi (8). Biorąc pod uwagę rozwój sektora oraz zmieniające się prawo dotyczące zdrowia zwierząt może to być niewystarczające.

\section{Podsumowanie}

Przez ostatnie cztery dekady Europejskie Stowarzyszenie Ichtiopatologów dzięki ogromnej pasji i zaangażowaniu swoich członków rozwinęło się z małej organizacji $\mathrm{w}$ jedno $\mathrm{z}$ najlepiej funkcjonujących stowarzyszeń weterynaryjnych. Jego zdecydowanymi atutami są: pełen profesjonalizm, interdyscyplinarność, ciągły rozwój i otwartość na nowych członków. W kontekście wyzwań, które czekają hodowlę zwierząt w przyszłości, a także uwzględniając koncepcję Błękitnego Rozwoju (Blue Growth) (1), można przypuszczać, że organizację EAFP czeka świetlana przyszłość.

\section{Piśmiennictwo}

1.Da-Rocha J., Guillen Garcia J., Prellezo R.: (Blue) Growth accounting in small-scale European Union fleets. MARINE POLICY 2019, 100, 200-206, ISSN 0308-597X, doi: 10.1016/j.marpol.2018.11.036.

2. EAFP Students awards winners. B. Eur. Assoc. Fish. Pat. 2019, 39, 92.

3. Naumowicz K., Siwicki A. K., Terech-Majewska E.: Osiemnasta międzynarodowa konferencja „Choroby ryb i mięczaków”, Belfast, 3-8 09 2017. Komunikaty Rybackie 2017, 6, 39-42.

4. News and views EAFP Council elections. B. Eur. Assoc. Fish. Pat. 2019, 39, 89-90.

5. Ruiz M., Iglesias D., Darriba S., Rodríguez R., López C.: Epidemiological survey of digenean trematodes affecting razor clams, Ensisarcuatus, from Galicia (NW Spain). B. Eur. Assoc. Fish. Pat. 2012, 32, 3-13.

6. Small Grants Scheme. B. Eur. Assoc. Fish. Pat. 2019, 39, 134.

7. Start-up meeting of the EAFP students/early career researcher's group. B. Eur. Assoc. Fish. Pat. 2019, 39, 135.

8. Terech-Majewska E., Pajdak J., Siemionek J., Szweda W.: Ichtiopatologia w Polsce: przeszłość, teraźniejszość, przyszłość. Med. Weter. 2017, 73, 375-382.

Adres autora: lek. wet. inż. Karolina Naumowicz, ul. Oczapowskiego 13, 10-719 Olsztyn; e-mail: karolina.naumowicz@uwm.edu.pl 